\title{
PKC-alpha Antisense Oligodeoxynucleotide ISIS 3521
}

National Cancer Institute

\section{Source}

National Cancer Institute. PKC-alpha Antisense Oligodeoxynucleotide ISIS 3521. NCI

Thesaurus. Code C1788.

A synthetic phosphorothioate oligodeoxynucleotide. As an antisense molecule, ISIS 3521 hybridizes to the 3-untranslated region of the human protein kinase C (PKC-alpha) mRNA, thereby inhibiting PKC-alpha expression and growth of PKC-alpha-dependent tumor cells. $(\mathrm{NCl04})$ 